DOI: https://doi.org/10.24843/JFU.2019.v08.i01.p05

pISSN: 2301-7716; eISSN: 2622-4607

Jurnal Farmasi Udayana, Vol 8, No 1, Tahun 2019, 29-35

\title{
Standardisasi Spesifik dan Non-Spesifik Simplisia dan Ekstrak Etanol 96\% Rimpang Kunyit (Curcuma domestica Val.)
}

\author{
Prabowo, H. ${ }^{1}$, Cahya, I.A.P.D. ${ }^{1}$, Arisanti, C.I.S. ${ }^{1}$, Samirana, P.O. ${ }^{1}$ \\ 1 Program Studi Farmasi Fakultas Matematika dan Ilmu Pengetahuan Alam Universitas Udayana, Jalan Kampus \\ Unud, Jimbaran, 80364. \\ E-mail:Heny.prabowo@gmail.com
}

\begin{abstract}
ABSTRAK
Kunyit (Curcuma domestica Val.) merupkan tanaman yang termasuk dalam famili Zingiberaceae. Kunyit sering dimanfaatkan sebagai obat tradisional seperti menyembuhkan luka, antibakteri, mengurangi motilitas usus, menghilangkan bau badan, obat demam, obat mencret, obat sesak napas, dan lain sebaginya. Standardisasi dilakukan dengan pengujian pada simplisia dan ekstrak rimpang kunyit. Standardisasi dilakukan untuk menjamin mutu bahan obat tradisional dan persyaratan terhadap reprodusibilitas terhadap kualitas farmasetik maupun terapetik. Parameter yang digunakan adalah makroskopik, mikroskopik, uji kadar abu total, uji kadar abu tidak larut asam, uji kadar sari larut air, uji kadar sari larut etanol, susut pengeringan, dan skrining fitokimia secara kualitatif. Dari hasil didapatkan bahwa simplisia rimpang kunyit memenuhi persyaratan, sedangkan ekstrak rimpang kunyit tidak memenuhi persyaratan parameter kadar abu tidak larut asam, dikarenakan pengotor yang mengontaminasi ekstrak berupa silika dan pasir. Silika dapat melukai pada mukosa tenggorokan apabila digunakan secara oral. Sehingga, ekstrak diyatakan belum layak dan belum dapat digunakan untuk perlakuan selanjutnya.
\end{abstract}

Kata kunci: Kunyit, Curcuma domestica, Standardisasi, Ekstrak, Simplisia.

\section{ABSTRACT}

Turmeric is a plant that included in Zingiberaceae. Turmerics often used as a traditional medicine to beal wounds, antibacterial, reduces intestine motility, reduce unpleasant body odor, treats fever, diarrhea, and many more. Standardization is performed by examining turmeric rbizome simpicia and extract. Standardization is carried out to guarantee the quality of traditional raw materials and requirements for reproducibility of pharmaceutical and therapentic qualities. Parameters that have been used in this research are macroscopic test, microscopic test, total ash content test, acid insoluble ash content test, water soluble simplicia content test, ethanol soluble simplicia content test, sbrinkage drying test, and Phytochemistry screening qualitatively. From the results, turmeric simplicia has met the requirements, while turmeric extract has not eligible in requirements, because its acid insoluble ash content are not eligible. This expected because of the impurities which contamine the extract are silica and sand. Silica can cuts the mucosa of the throat when used it orally. Turmeric extract in this research does not eligible and cannot be used for the next step.

Keywords: Turmeric, Curcuma domestica, Standardization, Extract, Simplicia. 
DOI: https://doi.org/10.24843/JFU.2019.v08.i01.p05

pISSN: 2301-7716; eISSN: 2622-4607

Jurnal Farmasi Udayana, Vol 8, No 1, Tahun 2019, 29-35

\section{PENDAHULUAN}

Obat tradisional merupakan ramuan campuran dari bahan-bahan yang bersumber dari tumbuhan, hewan, mineral, ataupun sediaan galenik, atau campuran ramuan tersebut digunakan sebagai pengobatan secara turun-temurun didasarkan atas pengalaman. Pengobatan secara tradisional saat ini mulai mendapatkan perhatian masyarakat, dimana dipercaya bahwa obat yang berasal dari tanaman atau sering disebut sebagai obat herbal aman digunakan tanpa adanya takaran dosis yang pasti (Supriyatna dkk, 2014), serta mudah dijangkau oleh masyarakat.

Tanaman yang selalu menjadi andalan sebagai pengobatan tradisional salah satu diantaranya adalah rimpang kunyit. Rimpang kunyit dapat dimanfaatkan sebagai obat tradisional seperti menyembuhkan luka, antibakteri, mengurangi motilitas usus, menghilangkan bau badan, menurunkan demam, meredakan diare dan beberapa pengobatan lainnya, hal ini karena adanya kandungan senyawa fitokimia pada kunyit tersebut. Rimpang kunyit mengandung minyak atsiri (felandren, sineol, borneol, zingiberen, tirmeron), demetoksikurkumin, dan bisdemetoksikurkumin (Winarto dan Tim Lentera, 2004).

Rimpang kunyit memiliki kandungan kimia yaitu zat warna kuning yang disebut kurkuminoid. Kurkuminoid dapat bersifat sebagai antioksidan, dimana dapat mencegah kerusakan sel-sel yang diakibatkan radikal bebas. Selain itu kurkuminoid juga dapat menjadi anti inflamasi (Winarto dan Tim Lentera, 2004)..

Standardisasi terdiri dari proses analisis kimiawi yang mengacu pada data farmakologis, serta analisis fisik dan mikrobiologi yang didasarkan kriteria toksikologi yang terstandardisasi pada ekstrak bahan alam (Saefudin et al., 2011). Penentuan standard harus didasarkan peraturan dan perundangundangan yang berlaku. Proses standardisasi harus dilakukan dengan berbagai macam metode pengujian (Parwata, 2017). Standardisasi harus dilakukan untuk menjamin mutu suatu bahan baku obat tradisional untuk dijadikan sediaan dan syarat dapat terjadinya reprodusibilitas terhadap kualitas sediaan maupun efek terapinya.

Standardisasi didasarkan pada senyawa aktif, ataupun senyawa penandanya jika senyawa aktif masih belum teridentifikasi atau masih diduga. Standardisasi dilakukan secara fisika, kimia, dan biologi (Purwata, 2017).

Pada penelitian kali ini digunakan ekstrak etanol rimpang kunyit untuk distandardisasi. Standardisasi dilakukan berdasarkan parameter yang terdapat di standar Farmakope Herbal Indonesia (2008) pada simplisia dan ekstrak dengan menggunakan parameter yaitu; susut pengeringan, penetapan kadar abu total, kadar abu tidak larut asam, kadar sari larut air, kadar air, kadar sari larut etanol, dan skrining fitokimia.

\section{METODE PENELITIAN}

\section{Alat}

Pada penelitian ini adapun alat yang digunakan meliputi alat-alat gelas Pyrex ${ }^{\circledR}$, vial, batang pengaduk, oven (BINDER), pipet tetes, viscometer Brookfield (DV-E), seperangkat alat destilasi, $\mathrm{pH}$-meter digital, beker glass, hot platedengan magnetic stirer (CORNING PC-4200), timbangan digital analitik (ADAM AFP-360L), botol kaca gelap, kertas perkamen, alumunium foil, sendok 
DOI: https://doi.org/10.24843/JFU.2019.v08.i01.p05

pISSN: 2301-7716; eISSN: 2622-4607

Jurnal Farmasi Udayana, Vol 8, No 1, Tahun 2019, 29-35

tanduk, botol sirup $60 \mathrm{~mL}$ dan cawan porselen, tanur, oven.

\section{Bahan}

Pada penelitan ini, bahan yang digunakan adalah Rimpang Kunyit, etanol 96\%, sukrosa, CMC-Na, akuades, minyak permen, asam sitrat dan Natrium Benzoat semua bahan memiliki grade pro analisis.

\section{Prosedur Penelitian}

\section{Pembuatan serbuk simplisia}

Rimpang kunyit segar dicuci terlebih dahulu untuk menghilangkan kontaminasi pengotor serta benda asing lain yang tidak diinginkan. Kemudian simplisia diblender lalu dikeringkan di oven dengan suhu $50^{\circ} \mathrm{C}$ hingga diperoleh kadar air $<10 \%$.

\section{Uji Makroskopis}

Pemeriksaan makroskopik dilakukan secara visual mengenai bentuk, warna dan bau.

\section{Uji Mikroskopis}

Pengamatan uji mikroskopis dilakukan dengan mikroskop menggunakan pembesaran tertentu yang disesuaikan dengan simplisia kunyit yang diuji, yaitu berupa serbuk. Pemeriksaan mikroskopik anatomi jaringan kunyit mempunyai ciri yaitu terdapat gumpalan sel, parenkim, dan rambut penutup.

\section{Susut Pengeringan}

Sebanyak 2 gram serbuk simplisia ditimbang dengan menggunakan botol timbang. Botol timbang yang digunakan terlebih dahulu dipanaskan selama 30 menit dengan suhu $105^{\circ} \mathrm{C}$ dan kemudian ditara. Botol timbang yang berisikan serbuk simplisia digoyangkan terlebih dahulu untuk meratakan serbuk yang ada di dalamnya, sampai terbentuk lapisan dengan tebal $5 \mathrm{~mm}$ hingga $10 \mathrm{~mm}$, di pindahkan ke dalam oven dengan tutup terbuka pada suhu $105^{\circ} \mathrm{C}$ sehingga bobot serbuk pada botol timbang tetap. Sebelum dikeringkan di dalam oven, botol ditutup dan dibiarkan mendingin dalam desikator hingga suhunya mencapai suhu kamar. Kadar susut pengeringan dihitung dalam $\% \mathrm{~b} / \mathrm{b}$.

\section{Kadar Abu Total}

Sebanyak 2 gram serbuk simplisia ditimbang dan diletakkan ke dalam krus silika yang sebelumnya sudah dipijar kemudian ditara. Dipijarkan serbuk simplisia yang ada di dalam krus hingga arang habis, selanjutnya didinginkan kemudian ditimbang bobotnya hingga memperoleh bobot yang tetap. Kadar abu total dihitung terhadap bobot serbuk awal dalam \%b/b (Kemenkes RI, 2014).

\section{Kadar Abu Tidak Larut Asam}

Pada uji kadar abu total, abu yang dihasilkan dipanaskan $\mathrm{HCl}$ encer $\mathrm{P}(10 \%) 25$ $\mathrm{mL}$ selama 5 menit. Abu kemudian disaring menggunakan kertas saring bebas abu, lalu dicuci dengan air panas untuk mengumpulkan abu yang tidak larut asam, kemudian dipijarkan dengan krus porselin dalam tanur pada suhu $600^{\circ} \mathrm{C}$ selama \pm 6 jam hingga diperoleh abu dengan bobot yang tetap, kemudian ditimbang. Kadar dihitung terhadap bobot awal serbuk, dinyatakan dalam \%b/b (Depkes RI, 2008).

\section{Kadar Sari Larut Air}

5 gram serbuk simplisia yang sudah dikeringkan, dilarutkan dengan $100 \mathrm{~mL}$ air kloroform P, dalam labu Erlenmeyer. Pada 6 jam pertama dikocok dengan shaker kemudian 18 jam berikutnya didiamkan. Selanjutnya sari, disaring sebanyak $20 \mathrm{~mL}$ dan filtrat diuapkan hingga kering dalam cawan porselin. Selanjutnya, sisa filtrat dipanaskan pada suhu 
DOI: https://doi.org/10.24843/JFU.2019.v08.i01.p05

pISSN: 2301-7716; eISSN: 2622-4607

Jurnal Farmasi Udayana, Vol 8, No 1, Tahun 2019, 29-35

$105^{\circ} \mathrm{C}$ hingga bobotnya tetap. Kadar dalam persen sari air dihitung terhadap bobot serbuk awal dalam \% b/b (Depkes RI, 2008).

\section{Kadar Sari Larut Etanol}

Serbuk simplisia sejumlah 5 gram yang sudah kering dan dilarutkan menggunakan 100 $\mathrm{mL}$ etanol (95\%), dalam labu Erlenmeyer. Pada 6 jam pertama sari dikocok dengan shaker dan 18 jam selanjutnya didiamkan. Sari yang telah didiamkan, disaring cepat untuk menghindarkan penguapan etanol (95\%) hingga $20 \mathrm{~mL}$, selanjutnya filtrat diuapkan sampai mengering pada cawan porselin. Sisanya dipanaskan pada suhu $105^{\circ} \mathrm{C}$ hingga bobotnya tetap. Kadar persen sari larut etanol (95\%) dihitung terhadap bobot serbuk awal dalam \% b/b (Depkes RI, 2008).

\section{Pembuatan Ekstrak}

Serbuk simplisia rimpang kunyit sebanyak 250 gram dimaserasi menggunakan pelarut etanol $96 \%$ dengan perbandingan (1:10) selama $24 \mathrm{jam}$. Setelah 1 hari, toples kaca dibuka kemudian maserat dan ampas dipisahkan. Maserat disaring lalu dihitung volumenya. Ampas yang diperoleh kemudian diremaserasi sebanyak 2 kali menggunakan pelarut etanol $96 \%$. Volume total maserat yang diperolehkemudin dihitung. Ekstrak yang diperoleh dari proses maserasi diuapkan pelarutnya dengan alat rotary vacum evaporator pada suhu $40^{\circ} \mathrm{C}$ hingga didapat ekstrak kental. Ekstrak kental yang diperoleh selanjutnya ditimbang dan dihitung persentasi rendemen yang diperoleh terhadap bobot serbuk simplisia. Rendemen dapat dihitung dengan cara;

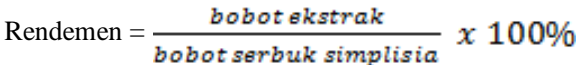

\section{Kadar Abu Total Ekstrak}

Ekstrak sebanyak 3 gram ditimbang lalu diletakkan kedalam krus porselin yang telah dipijarkan dan ditara. Ekstrak diratakan, lalu dipijarkan hingga arang habis dan terbentuk abu selama \pm 6 jam pada $600^{\circ} \mathrm{C}$, lalu didinginkan dan ditimbang hingga bobotnya tetap. Kadar abu total terhadap bobot ekstrak awal, dinyatakan dalam \%b/b (Kemenkes RI, 2014).

\section{Kadar Abu Tidak Larut Asam}

Penetapan kadar abu total dilakukan dengan abu yang didapat dari kadar abu total ekstrak ditambah $25 \mathrm{~mL} \mathrm{HCl}$ encer P $(10 \%)$ lalu dididihkan selama 5 menit. Abu yang tidak larut dalam asam dikumpulkan dengan cara disaring dengan kertas saring bebas abu, cuci dengan air panas, lalu dipijarkan pada tanur selama \pm 6 jam pada $600^{\circ} \mathrm{C}$ hingga bobotnya tetap dan ditimbang. Kadar abu yang tidak larut dalam asam dihitung terhadap bobot ekstrak awal, dinyatakan dalam \%b/b (Depkes RI,2008).

\section{Skrining Fitokimia}

Skrining dilakukan untuk mengetahui senyawa yang terkandung dalam ekstrak etanol rimpang kunyit. Pengujian terhadap dilakukan terhadap tanin, fenol, triterpen, minyak atsiri, saponin dan flavonoid. Uji dilakukan secara kualitatif. Pada uji tanin dan fenol, digunakan reagen $\mathrm{FeCl}_{3}$, dimana apabila warna berubah menjadi ungu biru menandakan adanya fenol dan tanin. Pada uji triterpenoid dan steroid, digunakan reagen asam asetat anhidrat dan $\mathrm{H}_{2} \mathrm{SO}_{4}$, dimana apabila terbentuk cincin kecoklatan menunjukkan adanya triterpenoid, sedangkan apabila warna cincin biru menunjukkan adanya steroid. Pada Uji saponin, ekstrak dikocok selama 10 detik dan apabila mengandung saponin terdapat busa yang stabil $>10$ menit setinggi $1-10 \mathrm{~cm}$ dan apabila diteteskan 1 tetel $\mathrm{HCl} 2 \mathrm{~N}$ busa tidak hilang. (Depkes RI, 2008). 


\section{HASIL DAN PEMBAHASAN}

Karakterisasi simplisia adalah syarat dimana bahan baku obat harus memenuhi persyaratan monografi yang tertuang dalam Farmakope Herbal Indonesia (Depkes RI, 2000).

Hasil penetapan makroskopis dan mikroskopis simplisia rimpang kunyit (Curcuma domestica Val.) dapat dilihat pada tabel 1 dan tabel 2. Pengamatan makroskopis dan mikroskopis dari simplisia rimpang kunyit telah sesuai dengan karakteristik organoleptis dan mikroskopis dari simplisia Curcuma domestica yang tertuang dalam FHI.

Standardisasi simplisia rimpang kunyit terdiri dari uji makroskopik dan mikroskopik, uji kadar abu, susut pengeringan, penetapan kadar sari larut air, kadar abu tidak larut asam, dan penetapan kadar sari larut etanol. Penyiapan simplisa dilakukan dengan memotong dan membersihakn rimpang kunyit, selanjutnya rimpang kunyit di oven dengan suhu 1050C untuk membuatnya kering dan lebih mudah diserbukkan. Pembuatan serbuk simplisia dapat memperkecil ukuran dari rimpang kunyit sehingga akan dapat meningkatkan luas permukaan rimpang kunyit dan akan mengoptimalkan proses ekstraksi. Pada uji kadar abu total, didapatkan kadar abu total sebesar 5,42\%. Dimana persyaratannya adalah kurang dari 8,5\%. Pada uji kadar abu tidak larut asam didapatkan $0,69 \%$, dimana persyaratannya adalah kurang dari $0,9 \%$. Untuk kadar sari larut air didapatkan 15,2\% dan larut etanolnya sebesar 49,9\%. Dimana, persyaratan kadar sari larut air simplisia rimpang kunyit adalah tidak kurang dari 11,5\% dan larut etanol tidak kurang dari 11,4\%.
Untuk susut pengeringan didapatkan 10,7\%, dan standar tidak lebih dari 12\%.

Tabel 1. Karakterisasi makroskopis dan mikroskopis simplisia rimpang kunyit

\begin{tabular}{|c|c|}
\hline Makroskopis & $\begin{array}{c}\text { Mikroskopis (Fragmen } \\
\text { pengenal) }\end{array}$ \\
\hline $\begin{array}{c}\text { Berbentuk } \\
\text { Memanjang } \\
\text { bercabang }\end{array}$ & Jaringan gabus \\
\hline $\begin{array}{l}\text { Berwarna Kuning } \\
\text { Jingga }\end{array}$ & $\begin{array}{c}\text { Sel parenkim dengan sel } \\
\text { kuning }\end{array}$ \\
\hline Bau khas kunyit & Jaringan pengangkut \\
\hline \multirow{3}{*}{$\begin{array}{c}\text { Rasa pahit dan agak } \\
\text { pedas }\end{array}$} & Rambut Penutup \\
\hline & Butiran amilum \\
\hline & $\begin{array}{c}\text { Sel parenkim dengan } \\
\text { amilum }\end{array}$ \\
\hline
\end{tabular}

Tabel 2. Karakterisasi kuantitatif dari simplisia rimpang kunyit

\begin{tabular}{ccc}
\hline Penetapan & Syarat FHI & $\begin{array}{c}\text { Hasil } \\
\text { penelitian }\end{array}$ \\
\hline $\begin{array}{c}\text { Susut } \\
\text { pengeringan }\end{array}$ & $<12 \%$ & $10,70 \%$ \\
\hline $\begin{array}{c}\text { Kadar Sari Larut } \\
\text { Air }\end{array}$ & $>11,5 \%$ & $15,2 \%$ \\
\hline $\begin{array}{c}\text { Kadar Sari Larut } \\
\text { Etanol }\end{array}$ & $<11,4 \%$ & $49,9 \%$ \\
\hline Kadar Abu Total & $<8,2 \%$ & $5,42 \%$ \\
\hline $\begin{array}{c}\text { Kadar Abu tidak } \\
\text { larut asam }\end{array}$ & $<0,9 \%$ & $0,69 \%$ \\
\hline
\end{tabular}

Tabel 3. Karakterisasi kuantitatif dari ekstrak rimpang kunyit

\begin{tabular}{ccc}
\hline Penetapan & Syarat FHI & $\begin{array}{c}\text { Hasil } \\
\text { penelitian }\end{array}$ \\
\hline Kadar Air & $<17 \%$ & $8,98 \%$ \\
\hline $\begin{array}{c}\text { Kadar Abu } \\
\text { Total }\end{array}$ & $<3,5 \%$ & $0,36 \%$ \\
\hline Kadar Abu & $<1,5 \%$ & $10,81 \%$ \\
\hline
\end{tabular}


Prabowo, dkk.

DOI: https://doi.org/10.24843/JFU.2019.v08.i01.p05

pISSN: 2301-7716; eISSN: 2622-4607

Jurnal Farmasi Udayana, Vol 8, No 1, Tahun 2019, 29-35

tidak larut asam

Pada standardisasi simplisia didapatkan bahwa serbuk simplisa rimpang kunyit memenuhi persyaratan.

Standardisasi ekstrak rimpang kunyit dilakukan dengan pengujian kadar abu total, kadar abu tidak larut asam, dan skrining fitokimia. Penetapan kadar air tidak dapat dilakukan karena reagen toluena yang tidak dapat digunakan dan tidak dapat digunakan metode gravimetri karena mengandung minyak atsiri. Pada uji kadar abu total adalah 0,36\%. Pada standar disebutkan tidak lebih dari $0,4 \%$. Pada uji kadar abu tidak larut asam adalah 10,81\%, dimana persyaratan tidak lebih dari $0,1 \%$. Hal ini tidak sesuai dengan persyaratan. Untuk skrining fitokimia, dilakukan pengujian terhadap tanin, fenol, triterpen, minyak atsiri, saponin dan flavonoid. Uji dilakukan secara kualitatif. Pada uji tanin dan fenol, digunakan reagen $\mathrm{FeCl}_{3}$, dimana apabila warna berubah menjadi ungu biru menandakan adanya fenol dan tanin. Pada ekstrak terdapat fenol dan tanin. Pada uji triterpenoid dan steroid, digunakan reagen asam asetat anhidrat dan $\mathrm{H}_{2} \mathrm{SO}_{4}$, dimana apabila terbentuk cincin kecoklatan menunjukkan adanya triterpenoid, sedangkan apabila warna cincin biru menunjukkan adanya steroid. Pada ekstrak terdapat triterpenoid. Pada Uji saponin, ekstrak dikocok selama 10 detik dan apabila mengandung saponin terdapat busa yang stabil $>10$ menit setinggi $1-10 \mathrm{~cm}$ dan apabila diteteskan 1 tetel $\mathrm{HCl} 2 \mathrm{~N}$ busa tidak hilang. Pada ekstrak terdapat saponin. Salain itu dilakukan uji flavonoid, dan pada ekstrak mengandung flavonoid.
Pada ektrak rimpang kunyit yang diperoleh, kadar abu tidak larut asam tidak memenuhi dari persyaratan. Hal ini menyatakan bahwa ekstrak tidak dapat digunakan untuk selanjutnya dibuat menjadi sediaan. Kadar abu tidak larut asam dihitung terhadap kadar abu total. Kadar abu total merupakan salah satu parameter kualitas dari suatu ekstrak. Penetapan kadar abu dilakukan dengan membuat ekstrak atau serbuk simplisia menjadi abu dalam krus di tanur dengan suhu $600^{\circ} \mathrm{C}$, pada tanur terjadi pemanasan bahan pada suhu ini senyawa organik dan turunannya dirusak dan diuapkan lebih cepat. Hal ini menyebabkan senyawa yang menjadi abu dan tertinggal yaitu senyawa/unsur mineral dan anorganik. Tujuan dari perhitungan kadar abu ini adalah mengetahui mineral yang terkandung secara internal maupun eksternal yang mengkontaminasi dari awal hingga akhir proses pembuatan ekstrak. Beberapa pengotor yang dapat mencemari adalah pasir, debu, tanah dan silika (Azizah dan Salamah, 2013).

Abu tidak larut asam dihitung dari bobot abu yang tdak larut dalam asam per bobot total abu keseluruhan. Kali ini didapatkan bobot abu total sebanyak 0,0074 gram dan bobot abu tidak larut asam sebanyak 0,0008 gram, maka total yang didapatkan 10,81\% dari kadar abu total tidak dapat larut dalam asam. Pengotor yang tidak larut asam ini dapat berupa silika ataupun pasir yang terdapat pada sampelsampel nabati (Sutomo dkk, 2017). Hal ini kemungkinan terjadi saat sedang pembuatan ekstrak, terdapat pengotor seperti pasir dan silika yang ikut mengontaminasi, sehingga menyebabkan kemurnian ekstrak berkurang dan kadar abu tidak larut asam ekstrak belum memenuhi persyaratan. 
DOI: https://doi.org/10.24843/JFU.2019.v08.i01.p05

pISSN: 2301-7716; eISSN: 2622-4607

Jurnal Farmasi Udayana, Vol 8, No 1, Tahun 2019, 29-35

Silika berbahaya apabila masuk ke dalam tubuh. Hal ini disebabkan senyawa silica memiliki bentuk mirip kaca yang sangat halus. terutama melalui oral, akan merobek jaringan sekitar mukosa tubuh, terutama tenggorokan.

\section{KESIMPULAN}

Standardisasi rimpang kunyit yang dilakukan pada penelitian ini menunjukkan bahwa simplisia telah memenuhi persyaratan makroskopis, mikroskopis, susut pengeringan, kadar sari larut air, kadar sari larut etanol, kadar abu total dan kadar abu larut asam telah memenuhi persyaratan. Pada ekstrak rimpang kunyit, uji kadar air tidak dilakukan, pada pengujian kadar abu total, ekstrak memenuhi standar, sedangkan pada pengujian kadar abu tidak larut asam, diperoleh hasil dimana ekstrak tidak memenuhi standar sehingga perlu dilakukan uji pemastian kembali terhadap ekstrak yang digunakan.

\section{UCAPAN TERIMAKASIH}

Terimakasih kami ucapkan kepada seluruh dosen yang telah membimbing kami, para laboran dan terlibat dalam penelitian dan semua pihak yang telah membantu dalam penelitian ini.

\section{DAFTAR PUSTAKA}

Budianto, N.E.W. 2014. Ekstrak Etanol Kunyit (Curcuma domestica Val) Dalam Mencegah Peningkatan Keasaman Lambung Rattus norvegicus Yang Diinduksi Histamin. Jurnal Ilmiah Kedokteran Vol.3(1): 48-56.

DepKes RI. 1980. Materia Medika Indonesia. Jilid IV. Jakarta: Departemen Kesehatan Republik Indonesia. Hal. 111; 113.

DepKes RI. 2000. Parameter Standar Umum Ekstrak Tumbuban Obat. Cetakan
Apabila dilihat dengan mikroskop, tepi dan ujung silika bentuknya runcing. Hal ini menyebabkan apabila masuk ke dalam tubuh Pertama.Jakarta: Departemen Kesehatan Republik Indonesia.

Depkes RI. 2008. Farmakope Herbal Indonesia. Edisi I. Jakarta: Departeman Kesehatan Republik Indonesia.

Menkes RI. 1994. Keputusan Menteri Kesehatan Republike Indonesia Nomor: 661/Menkes/SK/VII/1994 Tentang Persyaratan Obat Tradisional. Jakarta: Menteri Kesehatan Republik Indonesia.

Parwata, I.M.O.A. 2017. Bahan Ajar Obat Tradisional. Denpasar: Jurusan Kimia Laboratorium Kimia Organik Fakultas Matematika Dan Ilmu Pengetahuan Alam Universitas Udayana.

Rahayu, W.S., Tjiptasurasa, D. Indriyani. 2010. Kurkuminoid, Penetapan Kadarnya Pada Jamu Serbuk Temulawak (Curcuma xanthorriza Roxb) Secara Spektrofotometri Ultraviolet-Visibel. PHARMACY vol.7(2): 131-137.

Said, Ahmad. 2007. Khasiat dan Manfaat Kunyit. Jakarta: Sinar Wadja Lestari.

Saifudin, A., Rahayu, A., \& Teruna, H. Y., 2011. Standardisasi Bahan Obat Alam 2. Yogyakarta: Graha Ilmu.

Sutomo, N. Agustina, Arnida, Fadillaturrahma. 2017. Studi Farmakognostik dan Uji Parameter Nonspesifik Ekstrak Metanol Kulit Batang Kasturi (Mangifera casturi Kosterm.). Jurnal Pharmascience Vol. 4 (1): $94-101$

Supriyatna, dkk.2014. Prinsip Obat Herbal.Yogyakarta: Dee Publisher.

Winarto, W.P. dan Tim Lentera.2004.Kasiat dan Manfaat Kunyit. Jakarta: AgroMedia Pustaka. 